\title{
A VIRUS DISEASE OF OATS IN FINLAND SIMILAR TO OAT STERILE-DWARF DISEASE
}

\author{
KATRI IKÄHEIMO \\ Department of Plant Pathology \\ Agricultural Research Centre, Tikkurila
}

Received February 15, 1961

In western Finland, considerable damage has occurred in fields of oats infested by the leafhopper Calligypona pellucida F. (3). It was shown in 1959 that this leafhopper transmits wheat striate mosaic in Finland (1). Later it was found that leafhoppers collected from the fields on the western coast of Finland transmitted a disease of oats which differed in its symptoms from wheat striate mosaic. This disease in Finland closely resembles the oat sterile-dwarf disease transmitted by the leafhopper $C$. pellucida in Czechoslovakia $(5,6,8$.$) and a similar disease also occurs in$ Sweden (4).

\section{Symptoms of the disease in the glasshouse}

The symptoms of the disease in the oat variety Sisu, used in the glasshouse as a test variety, depend on the age of the plants at the time of infection. When infected at the $1-2$ leaf stage, the shoot grows more slowly and after $3-5$ weeks is thicker and stiffer with development of side-shoots at the base and often at the first node (Figs 1, 2, 3). This tillering continues so that the whole plant becomes bushy and dwarfed. The side-shoots are small and their leaves have short, broad blades. The number of side-shoots in one plant vary from 2 to 8 , sometimes up to 30 . The control plants infested with nonviruliferous insects usually have $0-1$ side-shoots. The infected plants are deep green in colour at first, but in the glasshouse yellowish mottling and occasionally also yellow, finally brown, spots or stripes appear later on the leaves of infected plants. Most plants infected at $1-2$ leaf stage do not form any panicles, or the panicle remains in the sheath. Plants infected at the later stages of growth develop panicles, which according to the earliness of the infection are blasted or have shrivelled grains. The number of side-shoots was also less than in plants infected at $1-2$ leaf stage. This disease very seldom kills plants and in this also it differs from wheat striate mosaic.

The deep green colour and tillering symptoms of the oat disease in Finland agree 


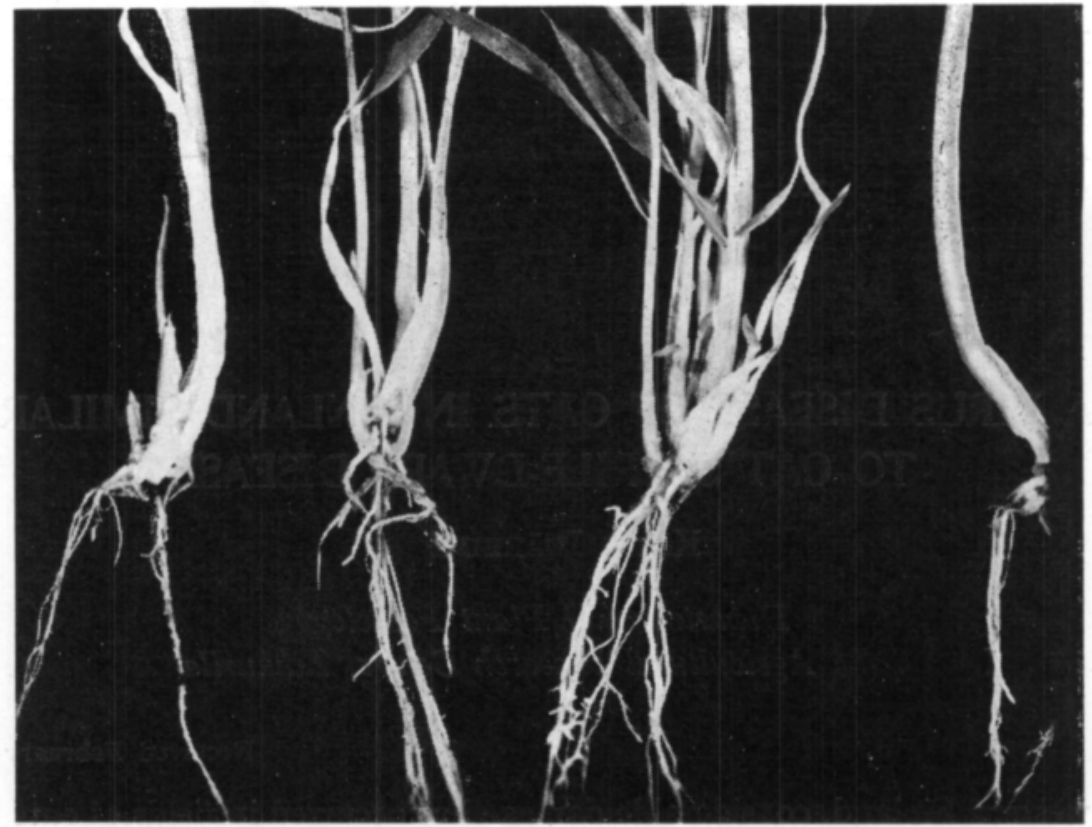

Fig. 1. Excessive tillering 5 weeks after infection. The plant on the right is healthy.

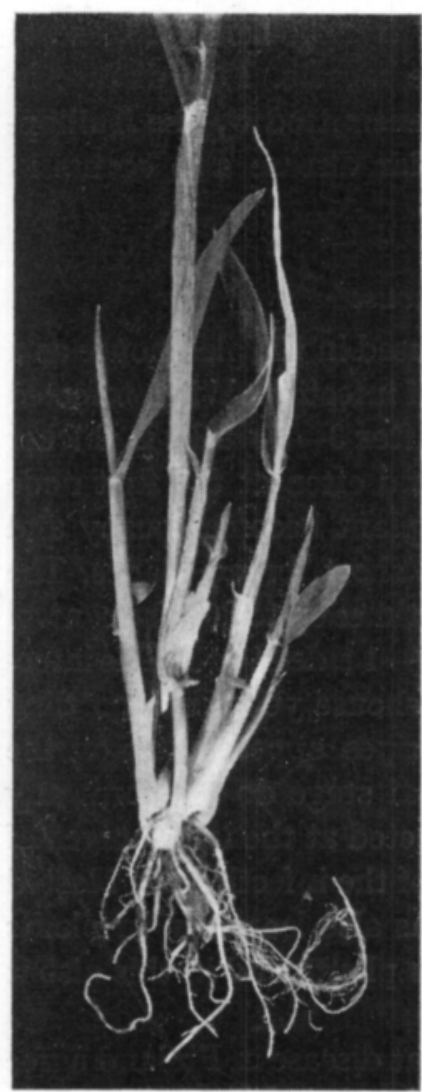

Fig. 2. Some basal shoots removed to show tillering at first node. Six weeks after infection. 


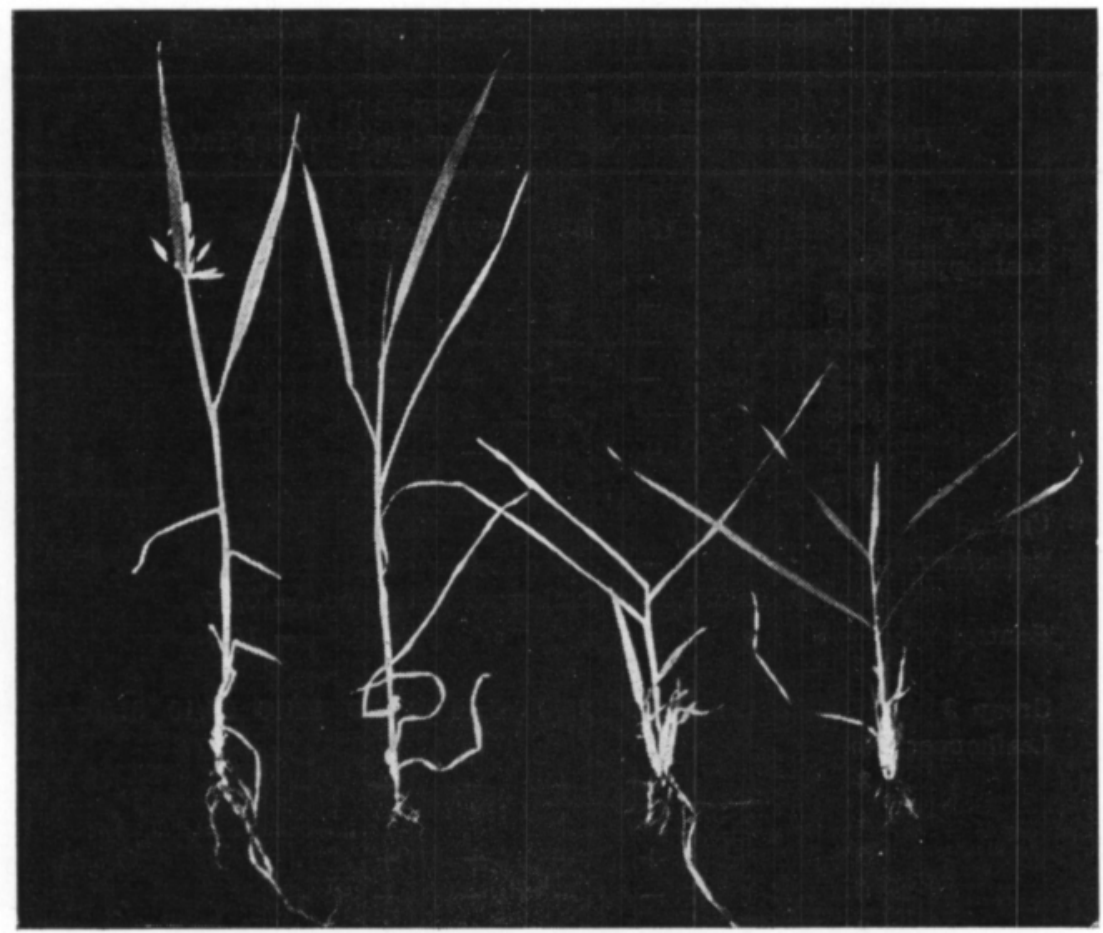

Fig. 3. Two diseased plants 7 weeks after infection. On the left two healthy plants.

with VAckes description of oat sterile-dwarf disease but clorotic lesions on the leaves are faint and in the glasshouse infected plants do not develop a red colour. According to VACKe (8) and PRÚ̌́a (5) the red colouration is typical of oat steriledwarf in Czechoslovakia and though it was found associated with dwarfed oat plants in Finnish oat crops in 1955 and $1956(2,3)$ this has been less noticeble reenctly.

\section{Transmission by leafhopper $C$. pell ucid a F.}

At the end of April 1960 leafhoppers were collected in the parish Sulva in the province of Pohjanmaa. About 500 nymphs at the 2 nd - 4th stages were caged on healthy Sisu oat seedlings in the glasshouse. Some of the nymphs were caged singly, others were caged in groups, each group containing $20-50$ nymphs. Thereafter the leafhoppers in these cages were transferred once a week to healthy oat plants. Inbred cultures of leafhoppers, each derived from different parents were obtained by collecting nymphs that had hatched from eggs laid on plants by a single caged female as described by Watson and SinHa (9).

During successive transfers of single leafhoppers and of one of the groups of leafhoppers, a small proportion of plants became infected by oat sterile-dwarf or by wheat striate mosaic or by both of these viruses.

Three groups of leafhoppers that did not infect any plants in these tests were chozen for controlled acquisition feeds on plants showing symptoms of oat sterile- 
Table 1. Transmission of oat sterile-dwarf by $C$. pellucida $\mathrm{F}$.

Acquisition feed 7 days. 1 nymph per plant.

Dates when leafhoppers were transferred to the new plants

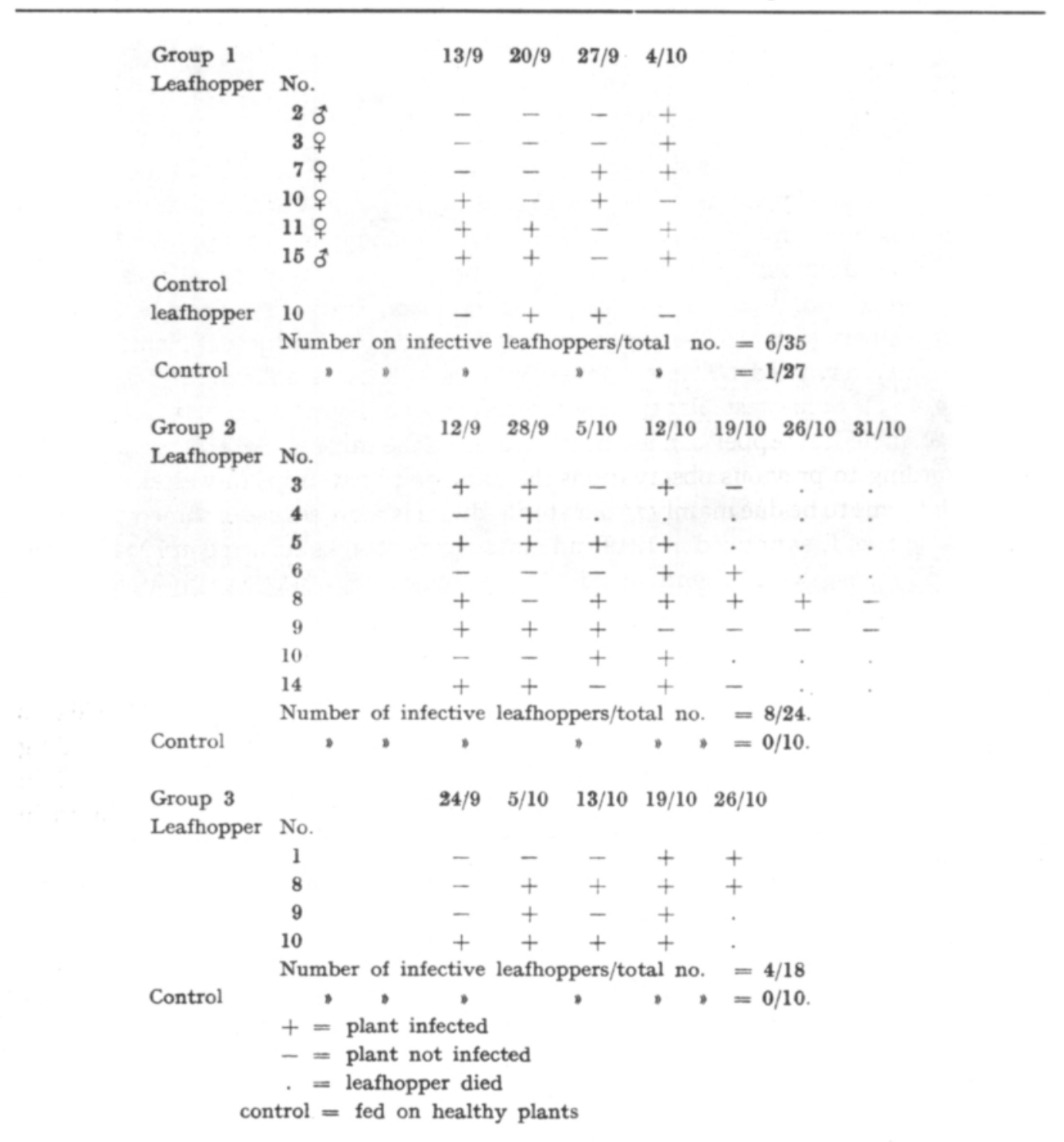

dwarf virus. Some of these leafhoppers at the 3rd and 4th nymphal stages were fed on infected plants for 7 days and tested singly for several weeks on a succession of plants, other leafhoppers of these cultures were tested at the same time to confirm that these were healthy, as shown in Table 1 . In the first group 6 out of 35 in the second group 8 out of 24 and in the third group 4 out of 18 leafhoppers transmitted the virus. All the control plants in groups 2 and 3 remained healthy but one of the controls in group 1 was infected. Leafhoppers in groups 1 and 2 were the progeny 
of several leafhoppers collected from Sulva parish which had bred freely during three generations. Leafhoppers in the third group were the progeny of one pair.

The incubation time of the virus seems to vary greatly; the shortest incubation time was 7 days and the longest 37 days, counting from the start of the acquisition feed. This agrees with the results of PRǓŠA et al. (6).

\section{Occurrence in the field}

The disease described here caused little harm in 1960, but in one field in the parish of Noormarkku in the province of Satakunta nearly half of the plants seemed to be infected by it and by wheat striate mosaic. Leafhopper nymphs were collected on the 23rd September from this field and caged in groups on thirty healthy oat plants at 3-leaf stage in the glasshouse, three insects on each plant. The thirty groups of hoppers were transferred at weekly intervals to healthy test plants. Striate mosaic was transmitted by nine of these groups and oat sterile-dwarf by eight of them (Table 2). Some test plants were infected by both viruses, but it is uncertain whether a single leafhopper carried both viruses at the same time.

According to previous observations the damage to oat crops in western Finland (3) which seems to be due mainly to oat sterile-dwarf is more severe in some years than in others. It was first noticed in 1949 and most severe attacks occurred in 1954-1956, when leafhoppers were abundant $(3,7)$, but since 1957 fewer leafhoppers have occurred (7). Present observations in many different parts of Finland in 1959 and

Table 2. Transmission of oat sterile-dwarf and wheat striate mosaic by $C$. pellucida $\mathrm{F}$.

Dates, when leafhoppers are transferred to new plants

\begin{tabular}{|c|c|c|c|c|c|c|c|}
\hline $\begin{array}{l}\text { Leafhopper } \\
\text { cage no. a }\end{array}$ & $23 / 9$ & $5 / 0$ & $13 / 10$ & $19 / 10$ & $26 / 10$ & $31 / 10$ & $9 / 11$ \\
\hline 1 & +0 & $+o$ & +0 & o. & o. & o. & 0 : \\
\hline 5 & 0 & - . & - : & - : & $-:$ & & : \\
\hline 7 & 0 & o & o & $\mathbf{o}:$ & o: & $0:$ & : \\
\hline 10 & + & + & - & + . & + . & + . & - \\
\hline 12 & + & + & + . & $+:$ & $+:$ & - : & - : \\
\hline 14 & + & + & - . & $-:$ & $-:$ & - : & - : \\
\hline 15 & + & + . & $+:$ & & : & : & : \\
\hline 16 & + & + & - & + : & + : & + : & + : \\
\hline 18 & o & o & o & o. & o. & o. & o. \\
\hline 19 & o & o & o & $-:$ & $-:$ & $-:$ & - : \\
\hline 20 & o & o & o &.- & o. & o. & - : \\
\hline 21 & - & + & + &.+ & + . & + . & + \\
\hline 25 & o & o & - & o & - . & - . & - . \\
\hline 27 & o & o & - & o &.- & - . & - . \\
\hline 30 & o & - & - & + & + . & + . & - . \\
\hline
\end{tabular}

$0=$ plant infected by the wheat striate mosaic virus

$+=$ plant infected by the oat sterile-dwarf virus

. = leafhopper died

$a=$ Three nymphs caged initially on each of 30 plants. 
1960 showed that oat sterile-dwarf infected only $1 \%$ or less of the plants in oat crops. The prevalence of the disease seems to depend on the abundance of leafhoppers.

Both viruses transmitted by the leafhopper $C$. pellucida seem to overwinter in the vector. Leafhoppers collected in Sulva parish on the 28th April 1960 transmitted both viruses immediately to healthy oat plants without any acquisition feed in the glasshouse. These nymphs were collected from a stubble of spring oats and wheat where some grass weeds had overwintered which might be hosts of these viruses. The weather had been cold during the whole of April, with an average of a little over zero, so it seems possible that the leafhoppers had not yet fed on the 28th April but had retained the virus acquired in the previous summer.

\section{$S u m m$ ary}

The leafhopper Calligypona pellucida F. transmits a virus that causes dark green colouration, dwarfing and excessive formation of side-shoots in oats. This disease is similar to oat sterile-dwarf but differs from wheat striate mosaic. The incubation time of oat sterile-dwarf virus in the vector varied from 7 to 37 days. This virus and the wheat striate mosaic virus can infect the same plant simultaneously and seem to overwinter in their leafhopper vector. It seems likely, that oat sterile dwarf became epidemic and caused great losses in yields of oats during some years of 1950 in western Finland.

Acknoweledgements. I wish to express my best thanks to Miss Sigrid Noelle for her technical assistance.

\section{REFERENCES:}

(1) Ікӓнегмо, К. 1960. Two cereal virus diseases in Finland. J. Sci. Agric. Soc. Finland 32: $62-70$.

(2) Jamalainen, E. A. 1957. Virustaudeista ja virustautien kaltaisista kasvitaudeista Suomessa. Summary: On the plant virus diseases and virus-like diseases in Finland. Valt. maatal.koetoim. julk. (Publ. Finn. State Agric. Res. Board) 158: 1-58.

(3) Kanervo, V., Heikinhermo, O., Rantikainen, M. \& Tinnilä, A. 1957. The leafhopper Delphacodes pellucida (F.) (Hom., Auchenorrhynca) as the cause and distributor of the damage to oats in Finland. Ibid. 160: 1-56.

(4) Lindsten, K. 1959. A preliminary report of virus diseases of cereals in Sweden. Phytopath. Z. 32: $420-428$.

(5) PRŮక̌ A, V., 1958. Die sterile Verzwegung des Hafers in der Tschechoslowakischen Rebublik. Ibid. 33: $99-107$.

(6) Prưša, V., Jermoljev, E. \& VACKe, J. 1959. Oat sterile-dwarf virus disease. Biol. Plant. 1: 223 - 234.

(7) RaAtrkainen, M. \& Tinnilä, A. 1959. Viljakaskaan (Calligypona pellucida F.) aiheuttaman tuhon vaikutus kauran viljelyalaan ja satoihin Suomessa. Summary: The effect of the damage to oats caused by Calligypona pellucida $\mathrm{F}$. on the acreages and yields of oats in Finland. $\mathrm{J}$. Sci. Agric. Soc. Finland 31: 49-66.

(8) VАске, J. 1960. Symptomatologie virovè sterilnosti a zakrslosti ovsa. Summary: Symptomatology of oat sterile-dwarf virus disease. Rostlinnà vyroba 6: 1049-1066.

(9) Watson, M. A. \& Sinha, R. C. 1959. Studies on the transmission of European wheat striate mosaic virus by Delphacodes pellucida Fabricius. Virology 8: 139-163. 


\title{
SELOST U S: \\ KAURAN TYVIVERSOVIROOSI, Oat sterile-dwarf-TAUDIN KALTAINEN VIRUSTAUTI SUOMESSA
}

\author{
KATRI IKÄHEIMO \\ Kasvitautien tutkimuslaitos \\ Maatalouden tutkimuskeskus, Tikkurila
}

Kasvitautien tutkimuslaitoksella suoritetuissa kokeissa viljakaskaan (Calligypona pellucida) todettiin levittävän vehnăn viirumosaiikkiviroosin (1) ohella tautia, joka aiheutti kaurassa pituuskasvun heikkenemistä ja epänormaalisen runsasta sivuversojen muodostumista. Tauti muistutti symptomeiltaan Tsekkoslovakiassa todettua oat sterile-dwarf virustautia $(5,6,8)$. Samanlaista tautia on esiintynyt myös Ruotsissa (4). Taudista käytetään tässă nimitystä kauran tyviversoviroosi.

Taudin symptomit vaihtelevat suuresti sen mukaan, minkä ikäisinä kasvit infektoituvat, ollen voimakkaimpia 1-2 lehtiasteella infektoituneissa kasveissa. Ensimmäinen taudin symptomi on kaurassa pituuskasvun hidastuminen. Samanaikaisesti korsi paksuntuu ja jäykkenee, sekä kasvin vihreä väri tummenee. Vähitellen korren tyveen ja myös ensimmäisen korren solmuun muodostuu sivuversoja (kuvat $1,2,3)$. Nämä ovat pienikokoisia, ja niiden lehdet ovat hyvin lyhyitä ja leveälapaisia. Sivuversoja muodostuu 2-8 kpl, joskus jopa $30 \mathrm{kpl}$. kasvia kohti. Useimmat $1-2$ lehtiasteella infektoituneet kasvit eivăt muodosta ollenkaan röyhyjä. Myöhäisemmällä kehitysasteella infektoituneet kasvit muodostavat röyhyjä, joissa esiintyy valkosuikaleisuutta ja kahujyväisyyttä. Kasvihuoneessa infektoiduissa kasveissa esiintyi kellanvihreäă kirjavoitumista ja joskus kellertäviä tai ruskehtavia laikkuja, jotka ovat tyypillisiä Tsekkoslovakiassa kuvatulle kasveissa. Muilta symptomeiltaan meillä todettu tauti on oat sterile-dwarf taudin kaltainen.

Taudin viroosiluonteen toteamiseksi suoritettiin virussiirrostuksia sairaista kasveista terveisiin kasveihin viljakaskaiden avulla. Kokeissa olleîsta kaskaista vain muutamat siirsivät virusta. Ensimmäisen ryhmän 35 :stä kaskaasta 6 , toisen ryhmän 24 :stä kaskaasta 8 ja kolmannen ryhmän 18 :sta kaskaasta 4 siirsi virusta sairaista kasveista terveisiin (taulukko 1).

Kauran tyviversoviroosia esiintyi kesällä 1960 yleensă varsin vähän. Noormarkussa oli kuitenkin kaurapelto, jossa lähes puolet kasveista oli virustautisia. Pellolta kerätyistä kaskaista osa siirsi vehnän viirumosaiikkivirusta ja osa kauran tyviversovirusta (taulukko 2).

N.s. kaurantuhon, joka näyttää olevan pääasiallisesti kauran tyviversoviruksen aiheuttama, esiintyminen vaihtelee aikaisemmin tehtyjen tutkimusten $(3,7)$ mukaan suuresti eri vuosina. Vuosina 19541956 tauti esiintyi hyvin voimakkaana. Vuosina 1955-1956 oli läntisellă rannikkoalueella Tuhoeläintutkimuslaitoksen suorittamien tutkimusten mukaan runsaammin kaskaita kuin vuonna $1957(3,7)$, jolloin tautia tavattiin vain vähän.

Kauran tyviversovirus samoin kuin vehnän viirumosaiikkivirus talvehtinee vektorissaan, viljakaskaassa. 